\title{
ANALISIS FAKTOR YANG MEMPENGARUHI STRUKTUR MODAL PADA PERUSAHAAN MAKANAN DAN MINUMAN YANG TERDAFTAR DI BURSA EFEK INDONESIA PERIODE 2013-2017
}

\author{
Mariska Leviani \\ Program Studi Magister Manajemen Universitas Tarumanagara \\ mariskaleviani95@gmail.com \\ Indra Widjaja \\ Program Studi Magister Manajemen Universitas Tarumanagara
}

\begin{abstract}
This research aimed to examine the effect of Liquidity (Current Ratio), Profitability (Return On Assets), Sales Growth, and Firm Size toward Capital Structure (Debt to Equity Ratio) on manufacturing companies sector food and beverages in Indonesia Stock Exchange for period 2013 - 2017. The sampling technique used was purposive sampling and the sample collected consisted of 14 companies. Analysis using SPSS program. Based on statistical $t$ test, the result of research show that Liquidity had a significant, negative effect on Capital Structure. Meanwhile, Profitability, Sales Growth, and Firm Size did not affect Capital Structure. Based on statistical F test indicates that variables Liquidity, Profitability, Sales Growth, and Firm Size simultantly affect Capital Structure on manufacturing companies sector food and beverage listed in Indonesia Stock Exchange for period 2013 - 2017.
\end{abstract}

Abstrak : Penelitian ini bertujuan untuk menguji pengaruh Likuiditas (Current Ratio), Profitabilitas (Return On Assets), Pertumbuhan Penjualan, dan Ukuran Perusahaan terhadap Struktur Modal (Debt to Equity Ratio) pada perusahaan manufaktur sektor makanan dan minuman yang terdaftar di Bursa Efek Indonesia periode 2013 - 2017. Teknik pemilihan sampel dalam penelitian ini menggunakan teknik purposive sampling dan sampel yang berhasil dikumpulkan berjumlah 14 perusahaan. Analisis data menggunakan program SPSS. Berdasarkan uji t, hasil dari penelitian ini menujukan bahwa Likuiditas memiliki pengaruh negatif dan signifikan terhadap Struktur Modal. Sementara itu, Profitabilitas, Pertumbuhan Penjualan, dan Ukuran Perusahaan tidak berpengaruh terhadap Struktur Modal. Berdasarkan uji F, Likuiditas, Profitabilitas, Pertumbuhan Penjualan, dan Ukuran Perusahaan secara simultan berpengaruh signifikan terhadap Struktur Modal.

Keywords : Liquidity, Profitability, Sales Growth, Firm Size, Capital Structure

\section{PENDAHULUAN}

Industri manufaktur nasional menunjukkan kinerja yang semakin agresif, dengan upayanya melakukan peningkatan pada ekspansi. Capaian ini didukung dari peran pemerintah dalam menciptakan iklim investasi yang kondusif serta memberikan kemudahan berbisnis kepada pelaku usaha di Indonesia. Pertumbuhan usaha manufaktur tersebut tidak terlepas dari komposisi dari struktur modal yang dimilikinya, yang mana emiten manufaktur lebih leluasa dalam berekspansi lantaran memiliki akses pendanaan di pasar modal.

Pertumbuhan sektor manufaktur salah satunya ditopang oleh pertumbuhan dari sektor makanan dan minuman. Pertumbuhan di sektor makanan dan minuman dapat menarik para investor untuk berinvestasi. Struktur modal memiliki peranan yang penting bagi kelangsungan perusahaan, terutama ketika perusahaan bermaksud melakukan ekspansi maka perusahaan harus menentukan berapa besarnya modal yang diperlukan untuk membiayai usahanya. Menurut Brigham dan Houston (2015: 465), menunjukkan bahwa struktur modal untuk perusahaan di masing-masing negara pada umumnya ditentukan oleh beberapa faktor yaitu 
ukuran perusahaan, profitabilitas, dan rasio aset tetap terhadap total aset. Sementara itu Antoni et al., (2016), menyebutkan bahwa faktor-faktor yang mempengaruhi struktur modal meliputi likuiditas, profitabilitas dan ukuran perusahaan. Menurut Jibran et al., (2012:87), salah satu aspek teori pecking order menyiratkan bahwa ketika menyangkut perusahaan yang menguntungkan, mereka akan selalu memilih pembiayaan internal daripada mengambil hutang baru atau ekuitas (pembiayaan eksternal).

Berdasarkan uraian permasalahan di atas, maka peneliti tertarik untuk mengkaji lebih lanjut mengenai pengaruh likuiditas, profitabilitas, pertumbuhan penjualan dan ukuran perusahaan terhadap struktur modal di perusahaan manufaktur sektor makanan dan minuman.

\section{TUJUAN PENELITIAN}

Penelitian ini dilakukan dengan beberapa tujuan yaitu untuk menguji pengaruh Likuiditas (Current Ratio), Profitabilitas (Return On Assets), Pertumbuhan Penjualan, dan Ukuran Perusahaan terhadap Struktur Modal (Debt to Equity Ratio) pada perusahaan manufaktur sektor makanan dan minuman yang terdaftar di Bursa Efek Indonesia periode 2013-2017.

\section{TINJAUAN PUSTAKA}

Pecking Order Theory. Menurut Jibran et al., (2012: 87), ketika menyangkut perusahaan yang menguntungkan, mereka akan selalu memilih pembiayaan internal daripada mengambil hutang baru atau ekuitas (pembiayaan eksternal) meskipun utang dianggap lebih murah daripada ekuitas dalam proporsi tertentu.

Trade off Theory. Menurut Ehrhardt dan Brigham (2011: 614), nilai dari perusahaan yang dipinjamkan sama dengan nilai perusahaan yang tidak ditimbang ditambah nilai efek samping, yang mencakup perisai pajak (tax shield) dan biaya yang diharapkan karena kesulitan keuangan (financial distress).

Struktur Modal. Menurut Paramasivan dan Subramanian (2012:47) adalah pembiayaan permanen perusahaan terutama yang diwakili oleh hutang dan ekuitas jangka panjang. Istilah struktur modal mengacu pada hubungan antara berbagai sumber pembiayaan jangka panjang seperti modal ekuitas, preferensi modal saham dan modal hutang. Dalam memutuskan struktur modal yang sesuai adalah keputusan penting manajemen keuangan karena berkaitan erat dengan nilai perusahaan.

Likuiditas. Menurut Kasmir (2017:130), Rasio likuiditas merupakan rasio yang digunakan untuk mengukur seberapa likuid nya suatu perusahaan. Penelitian yang dilakukan oleh Febriyanti dan Yahya (2017), Antoni et al (2016), serta Farisa dan Widati (2017) menyatakan bahwa likuiditas memiliki pengaruh signifikan terhadap struktur modal. Sementara, Seftianne (2011) menyatakan bahwa likuiditas tidak memiliki pengaruh signifikan terhadap struktur modal.

Profitabilitas. Menurut Kasmir (2017:196), Rasio profitabilitas merupakan rasio untuk menilai kemampuan perusahaan dalam mencari keuntungan baik dalam bentuk laba perusahaan maupun nilai ekonomis atas penjualan, aset bersih perusahaan maupun modal sendiri. Penelitian yang dilakukan oleh Seftianne (2011) menyatakan bahwa profitabilitas tidak memiliki pengaruh signifikan terhadap struktur modal. Sementara, penelitian yang dilakukan oleh Febriyanti dan Yahya (2017), menyebutkan bahwa profitabilitas berpengaruh signifikan terhadap struktur modal.

Pertumbuhan Penjualan. Menurut Fahmi (2014:69), Rasio pertumbuhan merupakan rasio yang mengukur seberapa besar kemampuan perusahaan dalam mempertahankan posisinya di dalam industri dan dalam perkembangan ekonomi secara umum. Penelitian yang dilakukan oleh Febriyanti dan Yahya (2017) menyatakan bahwa pertumbuhan penjualan berpengaruh tidak signifikan terhadap struktur modal. Sementara, Seftianne (2011) yang menyatakan bahwa ukuran perusahaan memiliki pengaruh signifikan terhadap struktur modal. 
Ukuran Perusahaan. Menurut (Febriyanti dan Yahya, 2017), Ukuran perusahaan yang besar, dianggap sebagai suatu indikator yang menggambarkan tingkat risiko bagi investor untuk melakukan investasi pada perusahaan tersebut, karena jika perusahaan memiliki kemampuan financial yang baik, maka diyakini bahwa perusahaan tersebut juga mampu memenuhi segala kewajibannya serta memberikan tingkat pengembalian yang memadai bagi investor. Penelitian yang dilakukan oleh Febriyanti dan Yahya (2017) menyatakan bahwa ukuran perusahaan berpengaruh tidak signifikan terhadap struktur modal. Sementara, Seftianne (2011) menyatakan ukuran perusahaan berpengaruh signifikan terhadap struktur modal.

Kerangka pemikiran dalam penelitian ini seperti yang digambarkan di bawah ini

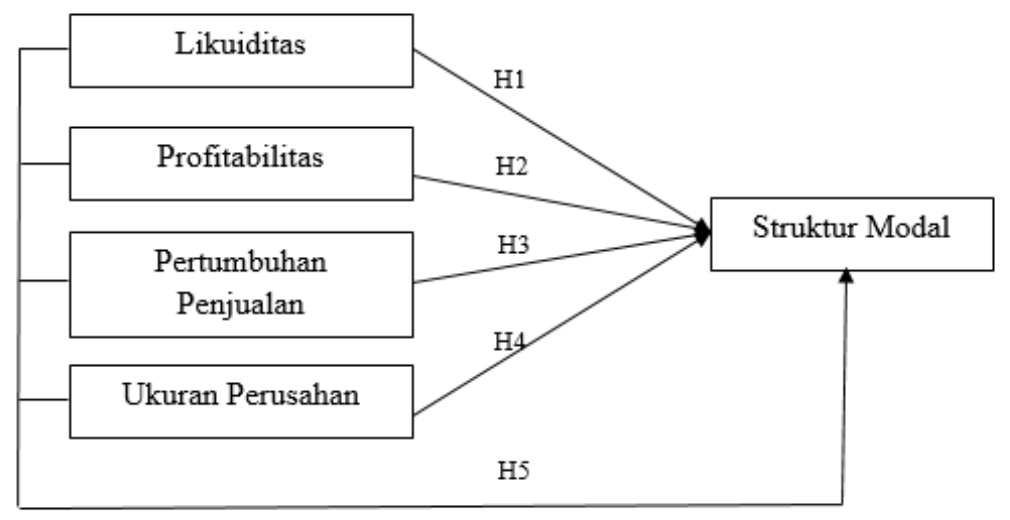

Gambar 1

Kerangka Pemikiran

Berdasarkan kerangka pemikiran di atas maka diperoleh hipotesis sebagai berikut:

H1 : Likuiditas secara parsial berpengaruh terhadap struktur modal.

H2 : Profitabilitas secara parsial berpengaruh terhadap struktur modal.

H3 : Pertumbuhan Penjualan secara parsial berpengaruh terhadap struktur modal.

H4 : Ukuran Perusahaan secara parsial berpengaruh terhadap struktur modal.

\section{METODOLOGI PENELITIAN}

Subjek penelitian ini adalah perusahaan Makanan dan Minuman yang terdaftar di Bursa Efek Indonesia periode 2013-2017 yang laporan keuangannya diperoleh dari www.idx.co.id. Adapun objek penelitian yang digunakan dalam penelitian ini adalah likuiditas, profitabilitas, pertumbuhan penjualan, ukuran perusahaan dan struktur modal.

Populasi dalam penelitian ini adalah laporan keuangan perusahaan manufaktur sub sektor makanan dan minuman dan sampel diambil dengan metode purposive sampling sesuai dengan kriteria yang telah ditentukan. Jumlah data yang terkumpul sebanyak 14 perusahaan.

Variabel operasional dalam penelitian ini terdiri dari likuiditas, profitabilitas, pertumbuhan penjualan, an ukuran perusahaan yang merupakan variabel independen dan struktur modal sebagai variabel dependen. Dalam penelitian ini struktur modal dihitung menggunakan Debt to Equity Ratio dengan formula:

$$
\text { Debt to Equity Ratio }=\frac{\text { Total liabilitas }}{\text { stockholders'equity }}
$$

Likuiditas. Dalam penelitian ini likuiditas dihitung menggunakan Current Ratio dengan formula:

$$
\text { Current Ratio }=\frac{\text { Aktiva Lancar }}{\text { Hutang Lancar }}
$$


Profitabilitas. Dalam penelitian ini profitabilitas dihitung menggunakan Return On Assets dengan formula:

$$
\text { Return On Assets }=\frac{\text { earning after interest and tax }}{\text { assets }} \times 100 \%
$$

Pertumbuhan Penjualan. Dalam penelitian ini pertumbuhan penjualan dihitung menggunakan Sales Growth dengan formula:

$$
\text { Pertumbuhan penjualan }=\frac{\text { penjualan } t-\text { penjualan } t-1}{\text { penjualan } t-1} \times 100 \%
$$

Ukuran Perusahaan. Dalam penelitian ini ukuran perusahaan dihitung menggunakan formula:

$$
\text { Size }=\text { Ln_Total Aset }
$$

Dalam penelitian ini menggunakan Uji Statistik Deskriptif untuk menggambarkan karakteristik atas variabel-variabel yang digunakan dalam suatu penelitian. Kemudian melakukan uji asumsi klasik yang terdiri dari Uji Normalitas, Uji Multikoliearitas, Uji Autokorelasi, dan Uji Heteroskedastisitas. Sedangkan uji hipotesis menggunakan Uji t, Uji F, Uji Koefisien Determinasi, dan Uji Analisis Korelasi Ganda.

\section{HASIL PENELITIAN}

Berdasarkan hasil statistik deskriptif, pada variabel likuiditas (X1) memiliki nilai minimal 0.514 dan maksimalnya yaitu 8.638. Nilai rata-rata yang dihasilkan sebesar 2.144 dengan standar deviasi sebesar 1.4898. Pada variabel profitabilitas (X2) memiliki nilai minimal -0.097058 dan maksimalnya yaitu 0.657201. Nilai rata-rata yang dihasilkan sebesar 0.101688 dengan standar deviasi sebesar 0.125126. Pada variabel pertumbuhan penjualan (X3) memiliki nilai minimal -0.317730 dan maksimalnya yaitu 1.273150 . Nilai rata-rata yang dihasilkan sebesar 0.153043 dengan standar deviasi sebesar 0.284204 . Selanjutnya pada variabel ukuran perusahaan (X4) memiliki nilai minimal 12.618 dan maksimalnya yaitu 18.335. Nilai rata-rata yang dihasilkan sebesar 14.88 dengan standar deviasi sebesar 1.472. Sementara itu pada variabel struktur modal sebagai variabel terikat memiliki nilai minimal 0.171 kali dan maksimalnya yaitu 3.029 kali. Nilai rata-rata yang dihasilkan sebesar 1.014 dengan standar deviasi sebesar 0.498 .

Agar data dapat dianalisis lebih lanjut, maka data penelitian harus memenuhi uji asumsi klasik. Pertama dilakukan Uji Normalitas dengan menggunakan kolmogorov smirnov. Dalam metode ini, data dikatakan normal apabila tingkat signifikansi mencapai $>0.05$. Hasil menunjukkan tingkat signifikansi yaitu 0,200 sehingga dapat dikatakan bahwa data penelitian telah berdistribusi normal. Selanjutnya dilakukan Uji Multikolinearitas. Hasil pengolahan data menunjukkan bahwa semua variabel berada pada tolerance di atas 0.1 dan VIF (Variance Inflation Factor) berada di bawah 10. Sehingga disimpulkan bahwa semua data yang diuji tidak terdapat gejala multikolinearitas. Uji berkutnya adalah Ui Autokorelasi. diperoleh nilai Durbin Watson (DW) sebesar 1,354. Menurut Santoso (2014: 194), angka D-W di antara -2 sampai +2 , berarti tidak ada autokorelasi. Dengan demikian dapat dikatakan bahwa data yang digunakan dalam penelitian ini tidak ada autokorelasi. Pengujian berikutnya adalah Uji Heteroskedastisitas Hasil pengujian heterokedastisitas, menunjukkan bahwa semua variabel independen bebas dari heteroskedastisitas karena variabel tersebut mempunyai tingkat signifikansi di atas 0.05 . Persamaan model regresi berganda yang digunakan dalam pengujian ini adalah:

$$
\mathrm{SM}_{\mathrm{it}}=1.959-0.232 \text { Liquid }_{\mathrm{it}}+0.318 \text { Prof }_{\mathrm{it}}-0.152 \text { Growth }_{\mathrm{it}}-0.031 \text { Size }_{\mathrm{it}}+\mathrm{e}
$$

Uji t dilakukan untuk mengetahui pengaruh variabel independen terhadap variabel dependen secara parsial. Berdasarkan analisis data diketahui nilai probabilitas signifikansi dari 
variabel likuiditas yaitu 0,0000 yang artinya likuiditas berpengaruh signifikan terhadap struktur modal. Berdasarkan analisis data diketahui nilai probabilitas signifikansi dari variabel profitabilitas yaitu 0,411 yang artinya profitabilitas tidak berpengaruh signifikan terhadap struktur modal. Berdasarkan analisis data diketahui nilai probabilitas signifikansi dari variabel pertumbuhan penjualan yaitu 0,374 yang artinya pertumbuhan penjualan tidak berpengaruh signifikan terhadap struktur modal. Berdasarkan analisis data diketahui nilai probabilitas signifikansi dari variabel ukuran perusahaan yaitu 0,325 yang artinya ukuran perusahaan tidak berpengaruh signifikan terhadap struktur modal.

Uji $\mathrm{F}$ dilakukan untuk melihat apakah keseluruhan variabel independen berpengaruh signifikan atau tidak signifikan terhadap variabel dependen. Hasil tersebut menunjukkan bahwa signifikansi yang dihasilkan sebesar 0.000 sehingga disimpulkan bahwa model regresi tersebut layak digunakan untuk memprediksi struktur modal. Hasil pengujian dengan regresi linear berganda menghasilkan nilai $R$ square sebesar 0,462 yang mana nilai tersebut menjelaskan bahwa 46,2\% dari variasi variabel struktur modal dapat dijelaskan oleh variabel likuiditas, profitabilitas, pertumbuhan penjualan dan ukuran perusahaan sedangkan faktorfaktor lain yang tidak dimasukkan ke dalam model penelitian ini dapat menjelaskan $53.8 \%$ dari variasi variabel struktur modal. Pada pengujian analisis korelasi ganda, menunjukkan hasil sebesar 0.680. Sehingga disimpulkan bahwa terdapat hubungan yang kuat antara variabel likuiditas, profitabilitas, pertumbuhan penjualan, dan ukuran perusahaan terhadap struktur modal. Hal tersebut dikarenakan nilai R berada di antara 0.60-0.799.

\section{HASIL DAN KESIMPULAN}

Berdasarkan hasil analisis data dapat ditarik kesimpulan bahwa variabel likuiditas berpengaruh negatif dan signifikan terhadap struktur modal. Sedangkan variabel profitabilitas, pertumbuhan penjualan, dan ukuran perusahaan tidak berpengaruh signifikan terhadap struktur modal pada perusahaan manufaktur sektor makanan dan minuman yang terdaftar di Bursa Efek Indonesia periode 2013-2017. Sedangkan Likuiditas, profitabilitas, pertumbuhan penjualan dan ukuran perusahaan secara simultan berpengaruh signifikan terhadap struktur modal perusahaan manufaktur sektor Makanan dan Minuman yang terdaftar di Bursa Efek Indonesia periode 2013-2017.

\section{DAFTAR PUSTAKA}

Antoni, Chandra, Chenita dan Susanti, Febsri. (2016). Faktor-Faktor Yang Mempengaruhi Struktur Modal Perusahaan Manufaktur Di Bursa Efek Indonesia. Jurnal Benefita, 1(2), ISSN: 2477-7862, 78-94.

Brigham, Eugene. F dan Houston, Joel. F. (2015). Fundamentals of Financial Management, Eleventh Edition. United States of America: Thomson South-Western, 465.

Jibran, Sheikh., Shakeel Ahmed. W, Waheed, Tahir M. M. (2012). Pecking at Pecking Order Theory: Evidence from Pakistan's Non-financial Sector. Journal of Competitiveness, 4(4), ISSN: 1804-1728, 86-95.

Ehrhardt, Michael C dan Brigham, Eugene F. (2011). Financial Management: Theory and Practice, Thirteenth Edition. Canada: Nelson Education, Ltd, 614.

Fahmi, Irham. (2014). Analisis Kinerja Keuangan. Bandung: Alfabeta, 69.

Kasmir. (2017). Analisis Laporan Keuangan. Jakarta: Raja Grafindo Persada.

Paramasivan, C dan Subramanian, T. (2012). Financial Management. New Delhi: New Age International (P) Limited, Publishers, 47.

Farisa, Nurul. A dan Widati, Listyowati. W. (2017). Analisa Profitabilitas, Likuiditas, Pertumbuhan Penjualan, Struktur Aktiva Dan Kebijakan Dividen Terhadap Struktur Modal. Prosiding Seminar Nasional Multi Disiplin Ilmu\& Call Papers Unisbank, 3, 640649. 
Febriyanti, Anisah. D dan Yahya. (2017). Pengaruh Ukuran Perusahaan, Profitabilitas, Likuiditas Dan Pertumbuhan Penjualan Terhadap Struktur Modal. Jurnal Ilmu dan Riset Manajemen, ISSN: 2461-0593, 6 (5), 1-18.

Santoso, Singgih. (2014). Statistik Parametrik: Konsep dan Aplikasi dengan SPSS. Jakarta: Penerbit PT Elex Media Komputindo, 194.

Seftianne. (2011). Faktor-Faktor Yang Mempengaruhi Struktur Modal Pada Perusahaan Publik Sektor Manufaktur. Jurnal Bisnis dan Akuntansi, ISSN:1410-9875, 13 (1), 39-56. 